\title{
Russia, China and the Shanghai Cooperation Organization: Diverging Security Interests and the 'Crimea Effect'
}

\author{
Marc Lanteigne
}

\begin{abstract}
The Shanghai Cooperation Organization (SCO) is an emerging security community created in 2001 to address looming threats, including terrorism and separatism, in the Central Asian region. China and Russia remain the major shapers of the SCO; but in recent years, differences over how the organization should evolve have begun to drive a subtle yet growing wedge between the two powers. Impending challenges related to expansion (India and Pakistan became full members in 2017), deepening Sino-Russian rifts (with China pushing for a stronger economic role for the organization, and Russia being more interested in hard security) and the 'shadow of Crimea' are likely to impede any Sino-Russian alliance in the foreseeable future.
\end{abstract}

Keywords Shanghai Cooperation Organization • Security • Russia • China • Multilateralism

M. Lanteigne $(\bowtie)$

Centre for Defence and Security Studies, Massey University, Auckland, New Zealand

(C) The Author(s) 2018

H. Blakkisrud, E. Wilson Rowe (eds.), Russia's Turn to the East,

Global Reordering, https://doi.org/10.1007/978-3-319-69790-1_7 
After a long period of isolation and, at times, open hostility, the end of the Cold War resulted in far more cordial diplomatic and strategic relations between Russia and China. Since the 1990s, there have been numerous examples of improved bilateral communication and cooperation, greater alignment of policies on regional security affairs, and sharing of mutual concerns about US-led security orders, including those in Asia and the Middle East. With the ascension to power of Xi Jinping in 2012 as President of China and the diplomatic and economic isolation of Russia in the wake of the 2014 annexation of Crimea, what has changed is the more pronounced shift in position in global hierarchies between these two great powers. China continues to move towards global power status in political, economic and strategic terms. By contrast, with the worsened relations between Moscow and the West, Russia is grappling with its own international status. While the Putin administration has experienced considerable ostracism over Ukraine, Beijing has continued to enhance its relations with Russia-but significant differences remain in the interests and viewpoints of the Kremlin and Beijing.

This chapter uses the case of the Shanghai Cooperation Organization (SCO) as a multilateral organization to argue that the 2014 Crimea crisis and the subsequent conflict in eastern Ukraine have further underscored the divergence in regional Eurasia policies between the SCO's two largest member states, Russia and China. Not only have the geopolitical and geostrategic aspects of the Ukraine crisis affected direct bilateral relations, they have also affected Sino-Russian behaviour within the SCO. While Russia continues to view the organization as a security regime with strong military dimensions, Beijing has pursued a more holistic and varied approach, accentuating the regime's security benefits while also seeking to develop a more expansive economic and diplomatic identity for the SCO. This chapter will also assert that it remains in Beijing's interest to keep the murky security situation in eastern Ukraine at arm's length, while maintaining its approach to Russia as a valuable, if often problematic, regional partner.

\section{A Troubled Pivot: Russia’s Turn to East Asia Under Putin}

Around the time of the Crimea crisis, China and Russia reached significant agreements in the areas of economic cooperation, as exemplified by the May 2014 natural gas agreement reportedly worth USD 400 billion (RT 
2014; Savic 2016), as well as in strategic areas. Moreover, even before the Crimea crisis, the Putin regime announced that, in view of the economic growth in the Asia-Pacific, East Asia would be a priority for Russian foreign policy. This proposed 'pivot to Asia' (Hill and Lo 2013; Storey and Tsvetov 2016) was an updated manifestation of the traditional 'West versus East'debate, the two-headed eagle ideological alignment question which had beset Russia since the times of the Empire (Westwood 1988; Neumann 1996). However, the diplomatic isolation and economic sanctions imposed on Russia after 2014 prompted an intensified policy of engaging East Asia, and especially China, in a search for alternative economic partners.

Due to the differing power trajectories of Beijing and Moscow, and their divergent views of regional and global security priorities, the possibility of a formal alliance between the two remains remote. Despite China's growth as a great power, Beijing has maintained a 'neo-Westphalian' policy stance, reflecting the idea that hegemonic power should not be overtly sought, and that great-power intervention in the domestic affairs of other states, especially developing ones, should be eschewed (Harris 2014, pp.1-23; Lanteigne 2016, p.9; Zhang 2016, pp.245-66). Such interventions should be undertaken only as a method of last resort, optimally through multilateral channels such as the UN Security Council. These concerns stem from China's long and difficult history of being subjected to colonialism in the pre-Maoist era, as well as China's status as a developing state sandwiched between two ambitious superpowers for much of the twentieth century (Wang 2012, pp.17-69).

For a long time, Moscow also advanced ideas about non-intervention, and expressed reservations about US activist foreign and security policy. These concepts, and the sanctity of state sovereignty, were constant themes in official Russian discourse during the crises in Kosovo in 1999 and later in Iraq, Libya and Syria (Wilhelmsen 2014). As Russian Foreign Minister Sergei Lavrov argued during a UN General Assembly session in September 2014 -incidentally some six months after Russia's own formal annexation of Crimea-'Shouldn't the General Assembly adopt a declaration on the inadmissibility of interference into domestic affairs of sovereign states and non-recognition of coups d'état as a method of the change of power?' (quoted in Gladstone 2014).

However, these views were being expressed while Russia under Putin was beginning to resist what was seen as ongoing US-led encroachment into the post-Soviet space that had been considered the Russian 'near abroad' since the breakup of the USSR. The Kremlin's unease over the 
'colour revolutions'-the Georgian 'Rose Revolution' in 2003, the 2004 'Orange Revolution' in Ukraine and the 'Tulip Revolution' in Kyrgyzstan in 2005-was followed by the Russian intervention in Georgia in 2008, a warning that Moscow was reaching the end of its patience with what it saw as its rapidly declining sphere of influence in Eurasia (Allison 2008; Way 2008; Pallin and Westerlund 2009). The 2013-2014 'Euromaidan' protests in Kiev, the Russian annexation of Crimea and the ongoing lowintensity conflict in eastern Ukraine can therefore be considered a culmination of Kremlin concerns about lost power and a shift towards a more realpolitik approach to the question of non-intervention. The increase in Russian military support for the Bashar al-Assad regime in the Syrian civil war is another manifestation of this view (Bagdonas 2012; Charap 2013). ${ }^{1}$

The divergent standings in international relations/hierarchies and views on sovereignty and non-intervention are key factors in understanding the evolving Sino-Russian relationship, especially in the security realm. Despite ongoing agreements and cordiality between the Putin and Xi governments, Russia after Crimea has begun to deviate more sharply from Chinese strategic thinking. In addition to the bilateral relationship, the policies of China and Russia within the SCO, the most mature security regime in Eurasia since its creation in 2001, provide stark evidence of these differing views. While the two great powers continue to seek ways of strengthening their relationship, including within the SCO, the possibility of a Sino-Russian alliance and the transformation of the SCO as a platform for such a pact is a non-starter. This was evident even before the events of 2014, but the post-Crimea crises have driven a sharper wedge between China and Russia over the trajectory of the SCO as well as the organization's developing identity.

\section{The Shanghai Cooperation Organization: An Overview}

Since the 1990s, Chinese policies on multilateral security have indicated greater acceptance of the need for regional-level problem solving. This view supports Russia's concerns about maintaining security in its 'near abroad', especially among the still-fragile states in Central Asia. Both great powers have also been wary of the Cold-War-era hierarchical and alliancebased forms of cooperation (such as the North Atlantic Treaty Organization 
[NATO]) favoured by the West, arguing that modern security problems necessitate new thinking on more effective cooperation in addressing threats above the state level. It was also during the 1990s that Beijing decided to depart from its traditional reluctance to shape regional security norms and organizations directly, and to assume a more active role in developing new tools to address security problems-especially on its periphery.

The most visible example of converging Sino-Russian policies has been the founding of the SCO, which grew out of the 'Shanghai Five' dialogues on ensuring peaceful regional development and settling leftover border disputes from the Soviet era (for more on the 'Shanghai Five' and the roots of the SCO, see the next section). The SCO brings together China, Russia and most of Central Asia, along with four observers, and six 'dialogue partners'. The membership was extended further outwards with a 2016 agreement welcoming former SCO observer states India and Pakistan as full members in 2017 (Ministry of Foreign Affairs of the Republic of Uzbekistan 2016). Turkmenistan, the only former Soviet Central Asian republic which is not a SCO member, periodically sends representatives to its meetings as 'guests', but remains outside the organization due to the country's commitment to 'permanent' or 'endless' neutrality (Polese and Horák 2015). Guest delegations have also been sent by the Association of Southeast Asian Nations (ASEAN) and the Moscow-led Commonwealth of Independent States (CIS). In November 2016, Turkish President Recep Tayyip Erdoğan announced Turkey's imminent application for full SCO membership as his government continued to distance itself from the West (Hasanova 2016) (Table 7.1).

Table 7.1 From the Shanghai Five to the SCO

Shanghai Five 1996-2001

\begin{tabular}{llll}
\hline Members & Members & Observers & Dialogue partners \\
\hline China & China & Afghanistan & Armenia \\
Kazakhstan & India & Belarus & Azerbaijan \\
Kyrgyzstan & Kazakhstan & Iran & Cambodia \\
Russian Federation & Kyrgyzstan & Mongolia & Nepal \\
Tajikistan & Pakistan & & Sri Lanka \\
& Russian Federation & & \\
& Tajikistan & & \\
& Uzbekistan & & \\
& & &
\end{tabular}


The SCO's initial mandate was to promote regional security and to protect its members from non-state security threats-especially terrorist organizations, ranging from local groups to more globalized entities such as al-Qaeda. The creation of the SCO could also be considered proof of the old axiom of nature abhorring a vacuum, as security cooperation in the region had previously been weak and untethered. SCO policymakers have frequently stressed that the organization is not an alliance, and is not balancing against the West or any other state-actor adversary; indeed, this position is codified in the organization's 2002 Charter (SCO 2002).

Moscow still acts as a 'big brother' in much of Eurasian politics and security; but in recent years, China has become a key economic partner for Central Asia, especially with the development (since 2013) of the 'Belt and Road' trade routes, featuring extensive participation by the states of Central Asia and Caucasus - as well as Russia_as conduits for overland trade between China and Europe (China Daily 2013; Putz 2016). The United States, by contrast, began to disengage from the region under the Obama administration. Although there were signs by the incoming Trump administration that US forces would remain in Afghanistan, US forces continue to be withdrawn from Afghanistan, albeit more slowly than predicted. The last US base in Central Asia, at Manas in Kyrgyzstan, was closed in 2014 (Pillalamarri 2014; Roberts 2016).

The decision to extend SCO membership to India and Pakistan significantly expands the geographic reach of the organization, and adds the considerable security problems of South Asia, such as the Kashmir conflict, to the SCO's already extensive agenda. The inclusion of India was a divisive issue, since Beijing was concerned about a dilution of its own role in the SCO, while Moscow viewed Indian membership as a way of checking Beijing's formidable influence within the group. Unlike the cordial IndiaRussia relations under the governments of Putin and Indian Prime Minister Narendra Modi, Sino-Indian relations have been quite cool during the past decade. This is due not least to periodic incursions by Chinese military forces into the two countries' border regions, including the April 2013 incident when a detachment of People's Liberation Army (PLA) forces camped for over a week in the disputed Daulat Beg Oldi area of Ladakh (Misra 2013, p.66). For its part, New Delhi remains concerned that China's economic diplomacy in South Asia- especially with Myanmar, Pakistan, Seychelles and Sri Lanka-may amount to a de facto containment plan against India's regional strategic interests. In this context, the India-Iran Chabahar development project agreed to in May 2016 can be 
a seen as a move countering China's ambitious port projects in the Indian Ocean (Hantke 2016; The Hindu 2016). The question remains whether the 2017 expansion of the SCO might diminish its decision-making power while unwittingly creating an arena for tacit China-India-Russia strategic competition.

The Putin regime has also supported Iran's interest in membership status-possibly further complicating the SCO's agenda, given ongoing questions about Teheran's nuclear development, and perhaps further diluting Beijing's status within the group. Given the Iranian nuclear question, Iranian admission could raise Western suspicions of the SCO, especially given the Trump administration's hostility towards Iran and opposition to the 2015 Iranian nuclear deal, and might significantly affect the SCO's official stance, supported by China, of non-alignment. Nonetheless, in June 2017, the Chinese Foreign Ministry publicly expressed its support for Teheran to become a member (Yang 2017). On the plus side for Beijing, Iranian membership may serve to bring China closer to Middle East affairs and markets, a region of growing importance for Beijing.

\section{Sino-Russian Relations and THe Evolution OF THE SCO}

The SCO was a product of the 'Shanghai Five' border dialogues in the late 1990s. In April 1996, China, Kazakhstan, Kyrgyzstan, Russia and Tajikistan signed a Five-Power Agreement in Shanghai. In addition to settling outstanding Soviet-era border concerns, the agreement regulated military activity in the frontier regions, prohibited provocative military exercises in those areas and called for strategic information-sharing, the conduct of joint exercises and increased military contacts among signatory states (Allen 2001, p.235).

In the bilateral Sino-Russian context, the agreement paved the way for more frequent meetings between military officials, more inspections and additional Chinese purchases of Russian weaponry. It also served to reduce tensions on a previously very tense borderland and provided another conduit for Sino-Russian cooperation. The final rounds of bilateral SinoRussian border negotiations were completed in 2004, further improving the strategic relationship and the climate for bilateral trade discussions (Wilhelmsen and Flikke 2011, pp.872-73)—not least on sales of fossil fuels, necessary to China because of its rapidly expanding economy. 
All five signatories agreed to maintain coordination of shared security concerns; the Shanghai Five thus became an important mechanism for Russia, China and Central Asia to address their strategic interests. By the end of the 1990s, the Taliban movement occupied most of Afghanistan, and nearby states became increasingly worried about the potential for spillover from that conflict into greater Eurasia. As a result, the region's 'three evils'-terrorism, extremism and 'splittism' / separatism-overtook border security concerns as the primary concern of the Shanghai Five (Chung 2004, pp.990-91). In addition to the Taliban, other regional terrorist threats included the Islamic Movement of Uzbekistan (IMU), a group dedicated to the overthrow of the Uzbek government and the establishment of a unified Islamic state in Central Asia, and the Hizb-ut Tahrir al-Islami, or Party of Islamic Liberation, which, despite its advocacy of non-violent struggle, was also viewed as a security risk, given its stated goal of establishing an Islamic caliphate in Central Asia (ICG 2002).

Beijing for its part had ongoing concerns about extremist activities in its Far West seeking to destabilize Chinese rule. The most prominent of these groups was the East Turkestan Independence Movement (ETIM), now known as the Turkistan Islamic Party (TIP) (Reed and Raschke 2010, pp.46-67). Since first being identified by Beijing in 2002, ETIM/TIP has been blamed for fomenting instability in China's Xinjiang region through bombings and attacks. Beijing has also linked the group to the larger alQaeda network (Sheives 2006, pp.209-10). For its part, TIP has claimed responsibility for a terrorist bombing in Beijing's Tiananmen Square in October 2013 and a knife attack at the Kunming train station in March 2014 (Buckley 2014; Kaiman 2013; Holdstock 2015).

The Shanghai Five assumed greater formalization and international visibility in 2001 when, on the occasion of welcoming Uzbekistan into the group, a declaration was signed which formed the genesis of the SCO. Shortly thereafter, the $9 / 11$ terrorist attacks occurred in the United States, further globalizing terrorism and highlighting the danger of extremism in Central Asia. The newly created SCO faced the challenges of deepening its security agenda, trying to balance strategic and non-strategic cooperation, and ensuring cooperation between Russia and China.

The organization's official charter, unveiled at its second conference in St Petersburg in June 2002, described the SCO's mandate as building 'mutual trust, friendship and good neighbourliness' while encouraging 'comprehensive cooperation' in security and related areas (SCO 2002). 
The document also introduced a Regional Anti-Terrorism Structure (RATS) to act as an information nexus for regional security. Based in Tashkent, RATS is currently the only such centre operating in Central Asia (Gill 2007, pp.130-31). Two years later, in 2004, a permanent SCO Secretariat was established in Beijing, with former Chinese Ambassador to Russia, Zhang Deguang, appointed as the organization's first secretary-general. ${ }^{2}$

The SCO has sought to coordinate joint military operations to improve confidence among members while creating a coordinated policy against potential threats. The first such exercises were held by China and Kyrgyzstan in October 2002, but were expanded to include all members except Uzbekistan in August of the following year (Chung 2006, p.10). The 2005 Peace Mission manoeuvres, conducted in the vicinity of Vladivostok, Russia, and in Weifang, Shandong Province, China, included joint strategic planning and a simulated offshore blockade and amphibious landing (Cohen 2006, p.56). Despite the apparent hard-security dimensions of the simulation, it was officially described as an anti-terror exercise. This pattern has continued: For example, the 2016 Peace Mission, held for the first time in Kyrgyzstan, included exercises involving the deployment of heavy weaponry as well as practice drills with air-to-air missiles (Kucera 2016).

Despite the regularity of the Peace Missions, there has not always been agreement between China and Russia as to their planning. For example, Beijing was unwilling to conduct the 2007 Peace Mission exercises in tandem with the Russia-dominated Collective Security Treaty Organization (CSTO) (Deng 2007). The latter includes all SCO members except for China and Uzbekistan, and the staunch Russian allies Armenia and Belarus.

\section{Security Debates Within the SCO}

The omnipresent military dimension of the SCO has led to debate over whether the organization is acting as the genesis of an eventual alliance or a possibly stronger anti-Western axis. However, these concerns are tempered by geopolitical realities that influence the differing security viewpoints of the two great powers; Sino-Russian policy differences have called into question the SCO's degree of leverage versus the West (Fels 2009, pp.23-28).

The relationship between the SCO and the CSTO remains a subject of debate. Beijing was not pleased about the recommendation introduced at 
the 2014 SCO Dushanbe summit of a merger between the two organizations (Salimov 2014). As the SCO has evolved, China has been comparatively much more enthusiastic than Russia about promoting the organization as a multifaceted entity with a strong economic and developmental dimension to match its security identity. Russia, by contrast, has been more supportive of the SCO as a regional power nexus to counter the West. For example, in 2008, Leonid Ivashov, General-Colonel and President of the Academy of Geopolitical Problems, made the nownotorious suggestion that the SCO should develop into 'the world's second pole' (Ivashov 2008).

Beijing has shared Moscow's unease about the 'colour revolutions' in the former Soviet space, with both powers tending to view those events as external interference designed to promote alternative pro-Western regimes (Shambaugh 2008, pp.87-92). Since the creation of the People's Republic in 1949, Beijing has been wary of Western attempts to undermine the legitimacy of the communist government, a process frequently denigrated as 'peaceful evolution' in Chinese policy circles. The Tulip Revolution in Kyrgyzstan prompted considerable internal debate in Beijing about regional security, leading to promises made by the government of $\mathrm{Hu}$ Jintao to fight a 'smokeless war' against 'liberal elements' seeking to destabilize China as they were apparently seeking to do in Central Asia (Kahn 2005). However, Beijing has been less enthusiastic than Moscow about using hard military means. During the July 2015 SCO Summit in Ufa, Russia, a recommendation by Russian Defence Minister Sergei Shoigu that the organization consider a more formal alliance which could serve to block any future 'colour revolutions' in Eurasia received a cold response from Beijing (Blank 2015).

The SCO has enabled Chinese policymakers to enhance regional friendship policies, adding weight to Beijing's policies of 'peaceful development' and becoming a 'responsible great power' via deeper engagement with regional economic and strategic organizations well beyond Eurasia or the Asia-Pacific (Glaser and Medeiros 2007; Johnston 2008, pp.148-49). In a 2013 speech at Nazarbayev University in Astana, Kazakhstan, Chinese President Xi Jinping described the fundamentals of a new 'Twenty-FirstCentury Silk Road' trade network, which later became a main component of the Chinese Belt and Road initiative (China Daily 2013). Xi also commented on the possibility of several regional organizations aligning more closely, specifically focusing on the potential for greater cooperation between the SCO and the Eurasian Economic Community (EAEC) 
(Xi 2014, p.317). In January 2015, the latter organization became the Eurasian Economic Union (EAEU), an organization dedicated to improving economic integration policies in the post-Soviet space.

Another example of differences between Beijing and Moscow over the 'non-security' identity of the SCO emerged in November 2016, when Chinese Premier Li Keqiang, in an attempt to further the economic dimension of the organization, recommended the creation of an SCO free trade zone, a long-standing interest in Beijing ever since the establishment of the SCO. However, Russian Prime Minister Medvedev responded by noting that such a regime would be a 'complicated matter given that any preferential regime always requires renunciation of internal decisions of one kind or another' (Russian Government 2016). Li also proposed the creation of an SCO-sponsored bank and development fund-another idea which was met with Russian misgivings. ${ }^{3}$

Despite statements stressing organizational unity following major SCO meetings, the separate policy directions favoured by the two great powers have become an open secret. In the wake of Russia's interventionist regional policies and the increasingly globalist foreign policies of $\mathrm{Xi}$, evidence that Sino-Russian policies within the SCO are divaricating has mounted.

\section{Georgia and Ukraine: The Cracks Get Wider?}

China's powerful position in Central Asia enabled the SCO to construct the most visible model of Beijing's 'New Security Concept' policies, developed at the end of the Cold War and stressing the widespread use of informal strategic cooperation and community-building rather than hierarchical alliances such as NATO (Foot 2006, p.85). With the Kremlin assuming a more assertive role in the post-Soviet space, China, despite unease with Russia's turn towards unilateral intervention (in Georgia and then in Crimea/eastern Ukraine), attempted to maintain its commitments to Russian ties and the development of the SCO.

Russia's August 2008 military intervention in the disputed Georgian territories of Abkhazia and South Ossetia, under the aegis of 'peace enforcement', was not well received by Beijing or the other SCO members. Although they recognized Russia's peacekeeping roles in the Caucasus, there was no SCO endorsement of the intervention despite Moscow's attempts to obtain the organization's formal backing. Chinese concerns about the Russia-Georgia conflict were numerous, including 
what was perceived as the circumvention of core Chinese views on the sanctity of borders and non-intervention policies, which Beijing hoped would be highlighted by the SCO. Concerns about a 'demonstration effect', especially after Russia called for the recognition of Abkhazia and South Ossetia as independent entities following the conflict, prompted China's relative silence on the crisis, save for a suggestion by a Foreign Ministry spokesperson that the conflict could be referred to the United Nations (Barriaux 2008; Liu 2016, p.151; Ministry of Foreign Affairs of the People's Republic of China 2008). The fact that military action began on the eve of the Beijing Summer Olympic Games, intended as a 'comingout party' for China on the global stage, did not help to mollify concerns in Beijing.

Difficult relations between Russia and Georgia since 2008 (Georgia withdrew from the CIS in August 2008 in protest at the Russian military actions) provided an opening for China to improve its own ties with Tbilisi. Beijing has declined to grant official recognition to the two breakaway republics, maintaining its diplomatic relations with Georgia and commencing bilateral free trade agreement (FTA) talks with Tbilisi in December 2015. The agreement, signed in May 2017, is the first FTA Beijing has concluded with a former Soviet republic. ${ }^{4}$ Georgia is also expected to be a component of the Silk Road overland trade routes, given its location, the potential for infrastructure development and the opportunity for Beijing to balance Russian interests in the Caucasus (Topuria 2016; Xinhua 2016). However, Chinese shipping through Georgia remains underdeveloped compared to the primary routes through Kazakhstan and Russia.

Russia's annexation of Crimea and the Russia-backed establishment in 2014 of 'people's republics' in Donetsk and Luhansk in eastern Ukraine were also challenges for Chinese diplomacy and its ability to juggle its Russian and Ukrainian interests. Russian involvement in the fighting in eastern Ukraine, and the July 2014 downing of a Malaysian civilian jetliner over rebel-held territories, allegedly by pro-Russian separatist forces, created a toxic diplomatic atmosphere between Russia and Europe and the United States. Beijing responded to these events by seeking to reconcile its Russian diplomacy with its stance on non-intervention in sovereign state affairs. At the 2014 SCO Summit in Dushanbe, Putin failed to secure formal support for Russia's interpretation of the Ukraine crisis: 
The summit declaration simply called for the restoration of peace through negotiations in war-torn eastern Ukraine (Lillis 2014).

Official statements from the Chinese government reiterated the country's long-standing policy that the territorial sovereignty of states be maintained, but stopped short of criticizing Russian actions. China did not support economic sanctions introduced by the United States and Europe. In March 2014, a Chinese Foreign Ministry spokesperson stated that while Beijing recognized and respected the role of non-interference and international law, 'we take into account the historical facts and realistic complexity of the Ukrainian issue' (Ministry of Foreign Affairs of the People's Republic of China 2014). During a May 2014 UN Security Council vote on non-recognition of the referendum on Crimean independence', China chose to abstain rather than join Russia in exercising a veto. Despite its hesitancy to align overtly against Russia, Beijing was anxious to avoid being labelled a 'spoiler' in this conflict. China has proceeded to promote a non-aligned approach to the question of Crimean sovereignty, and has maintained that the conflict in eastern Ukraine is best settled through negotiation (Reuters 2015).

This 'double game' being played out in bilateral relations between Beijing and Moscow is likely to dominate discussion on the future of the SCO as a security community and as a strategic actor. The cases of Georgia and Crimea provide insights into the divergence of ideas between China and Russia in regard to Eurasian diplomacy and the evolution of the organization. Moreover, within the SCO, these issues indicate growing unease on the part of Beijing over Russia's longer-term security interests in Eurasia, as well as Moscow's overall political health in light of its post2014 diplomatic ostracism. During World War I, a German general was said to have bitterly commented about his country's main ally, the peremptory but decaying Austro-Hungarian Empire: 'we are shackled to a corpse' (Taylor 2013, p.9). China very much wants to avoid that type of scenario, especially should power levels between the two great powers continue to diverge as China continues to grow to potential global power status. A likely wild card is the difficult relationship between the United States under Trump and the Putin regime (MacFarquar 2016), but also the differences between Trump and President Xi over economic and strategic issues. Beijing continues to view Russia as a close friend, but retains its interest in balancing hawkish Russian policies within the SCO, and eschewing the possibility of a formal alliance either bilaterally or within the SCO itself. 


\section{Conclusions: Same Bed, Different Dreams?}

Concerning intervention, it has been argued that Russia has taken on the role of a 'loud dissenter', repelling perceived unfair Western norms, while China has assumed the persona of a 'cautious partner', affiliating informally with Russia but stopping well short of formal alignment with Moscow, including within the confines of the SCO (Snetkov and Lanteigne 2015). Although it can be argued that policy divergence between China and Russia regarding SCO policy and identity existed long before the post-2014 Ukraine crisis, the annexation of Crimea and conflict in eastern Ukraine, like the Georgia conflict before it, have illustrated the widening of policy trajectories of the two great powers. Within the SCO, there remain fundamental differences regarding both the ideal security identity of the organization and the degree to which non-security issues such as economic cooperation should be incorporated within its framework.

Although military cooperation and coordination continue, including the Peace Mission exercises, Beijing remains wary of the SCO becoming a formal alliance as well as potentially affecting vital economic relations with the United States and its allies. At the May 2014 summit of the Conference on Interaction and Confidence Building Measures in Asia (CICA), the Xi government called for a new 'Asian' security concept (Xinhua 2014). Beijing has, however, compared with Moscow, preferred more comprehensive approaches to security cooperation. The Belt and Road agreements, potentially enhancing Chinese economic relations across Eurasia as well as with Europe, show that China sees security in these regions as important, but also as part of a larger diplomatic process that includes development, transportation and communication. The 2017 expansion of the SCO may pose challenges for Beijing as it seeks to prevent its voice being muted because of the inclusion of big powers India and Pakistan. However, there are also opportunities for China to better utilize an expanded SCO to further its Belt and Road economic and strategic interests, especially if further expansion to include Iran and Turkey takes place.

With China politically and economically developing a more independent and activist foreign policy, Beijing considers itself the alternative major power in Eurasian development. The SCO, a security organization still establishing its identity, has been at the forefront of Beijing's efforts to expand its strategic interests in Eurasia and solidify its security and, increasingly, its economic interests in this pivotal region. However, the case of the SCO further underscores Beijing's interests in retaining Russia as a 
valuable strategic partner, while also maintaining a discreet 'agree to disagree' stance on Moscow's post-Crimea Eurasian strategic policies.

\section{Notes}

1. The Bashar al-Assad government in Syria is one of Moscow's few remaining friends in the Middle East. Russia maintains a naval base at Tartus and, starting in September 2015, Russia has been active in military operations against the Islamic State.

2. The current SCO Secretary-General is Tajikistani diplomat Rashid Olimov, who assumed the position in January 2016 and who is expected to oversee the organization and its expansion until 2018 (Global Times 2016).

3. Under Xi, China was the driving force behind the establishment of a range of new financial institutions, including the Asian Infrastructure Investment Bank (AIIB) and the New Development Bank (NDB), in addition to the Silk Road Fund attached to the Belt and Road initiatives. Russia was a founding member of both the AIIB and the NDB.

4. Moldova, another ex-Soviet state experiencing erratic relations with Moscow, agreed in September 2016 to commence FTA talks in 2017 (TASS 2016; Xinhua 2017).

\section{REFERENCES}

Allen, Kenneth W. 2001. 'Confidence-building measures and the People's Liberation Army', in Remaking the Chinese state: strategies, society and security, edited by Chien-min Chao and Bruce J. Dickson, 228-56. London: Routledge. Allison, Roy. 2008. 'Moscow's campaign to "coerce Georgia to peace", International Affairs 84(6): 1145-71.

Bagdonas, Azuolas. 2012. 'Russia's interests in the Syrian conflict: power, prestige, and profit', European Journal of Economic and Political Studies 5(2): 55-77.

Barriaux, Marianne. 2008. 'China cannot back Russia in Georgia crisis: analysts', AFP, 30 August. http://macaudailytimes.com.mo/archive-2007-2009/ china-cannot-back-russia-in-georgia-crisis-analysts.html. Accessed on 18 February 2017.

Blank, Stephen. 2015. 'Was the SCO Summit in Ufa a breakthrough?' CACI Analyst, 19 August. https://www.cacianalyst.org/publications/analytical-articles/item/13261-was-the-sco-summit-in-ufa-a-breakthrough?.html. Accessed on 18 February 2017.

Buckley, Chris. 2014. 'Attackers with knives kill 29 at Chinese rail station', The New York Times, l March. https://www.nytimes.com/2014/03/02/world/ asia/china.html. Accessed on 18 February 2017. 
Charap, Samuel. 2013. 'Russia, Syria and the doctrine of intervention', Survival 55(1): 35-41.

China Daily. 2013. 'President Xi proposes Silk Road economic belt', 7 September. http://www.chinadaily.com.cn/china/2013xivisitcenterasia/2013-09/07/ content_16951811.htm. Accessed on 18 February 2017.

Chung, Chien-peng. 2004. 'The Shanghai Cooperation Organization: China's changing influence in Central Asia', The China Quarterly 180 (December): 989-1009.

Chung, Chien-peng. 2006. 'China and the institutionalization of the Shanghai Cooperation Organization', Problems of Post-Communism 53(5): 3-14.

Cohen, Ariel. 2006. 'After the G-8 summit: China and the Shanghai Cooperation Organization', China and Eurasia Forum Quarterly 4(3): 51-64.

Deng, Yong. 2007. 'Remoulding great power politics: China's strategic partnerships with Russia, the European Union, and India', Journal of Strategic Studies 30(4-5): 863-903.

Fels, Enrico. 2009. Assessing Eurasia's powerhouse: an inquiry into the nature of the Shanghai Cooperation Organisation. Bochum: Verlag Dr. Dieter Winkler.

Foot, Rosemary. 2006. 'Chinese strategies in a US-hegemonic global order: accommodating and hedging', International Affairs 82(1): 77-94.

Gill, Bates. 2007. Rising star: China's new security diplomacy. Washington, DC: Brookings Institution Press.

Gladstone, Rick. 2014. 'Russian diplomat's speech depicts the West as hypocritical', The New York Times, 28 September. https://www.nytimes.com/2014/09/28/ world/russian-diplomats-speech-depicts-the-west-as-hypocritical.html?_r=0. Accessed on 18 February 2017.

Glaser, Bonnie S. and Evan S. Medeiros. 2007. 'The changing ecology of foreign policy-making in China: the ascension and demise of the theory of "peaceful rise"', The China Quarterly 190 (June): 291-310.

Global Times. 2016. 'China stresses security cooperation as new SCO SecretaryGeneral takes office', 27 January. http://www.globaltimes.cn/content/ 965922.shtml. Accessed on 18 February 2017.

Hantke, André. 2016. 'Will India and Pakistan cripple the SCO?' The Diplomat, 9 November. http://thediplomat.com/2016/11/will-india-and-pakistan-cripple-the-sco. Accessed on 18 February 2017.

Harris, Stuart. 2014. China's foreign policy. Cambridge: Polity Press.

Hasanova, Gunay. 2016. 'Turkey eyes joining SCO', Azernews, 21 November. http://www.azernews.az/region/105405.html. Accessed on 18 February 2017.

Hill, Fiona and Bobo Lo. 2013. 'Putin's pivot: why Russia is looking east', Foreign Affairs, 31 July. https://www.foreignaffairs.com/articles/russian-federation/ 2013-07-31/putins-pivot. Accessed on 18 February 2017. 
The Hindu. 2016. 'India to develop Iran's Chabahar port', 24 May. http://www. thehindu.com/news/national/India-to-develop-Irans-Chabahar-port/article14336893.ece. Accessed on 18 February 2017.

Holdstock, Nick. 2015. China's forgotten people: Xinjiang, terror and the Chinese state. London: I.B. Tauris.

ICG. 2002. 'The IMU and the Hizb-ut Tahrir: implications of the Afghanistan campaign', 30 January. https://www.crisisgroup.org/europe-central-asia/ central-asia/uzbekistan/imu-and-hizb-ut-tahrir-implications-afghanistan-campaign. Accessed on 18 February 2017.

Ivashov, Leonid. 2008. 'Heartland expanding, or the Shanghai Cooperation Organization', 8 January. http://pocombelles.over-blog.com/article-24832397. html. Accessed on 18 February 2017.

Johnston, Alastair Iain. 2008. Social states: China in international institutions, 1980-2000. Princeton, NJ: Princeton University Press.

Kahn, Joseph. 2005. 'China's leader, ex-rival at side, solidifies power', The New York Times, 25 September. http://www.nytimes.com/2005/09/25/ world/asia/chinas-leader-exrival-at-side-solidifies-power.html. Accessed on 18 February 2017.

Kaiman, Jonathan. 2013. 'Islamist group claims responsibility for attack on China's Tiananmen Square', The Guardian, 25 November. https://www.theguardian. $\mathrm{com} /$ world $/ 2013 /$ nov/25/islamist-china-tiananmen-beijing-attack. Accessed on 18 February 2017.

Kucera, Joshua. 2016. 'SCO starts first-ever military exercises in Kyrgyzstan', Eurasianet.org, 19 September. http://www.eurasianet.org/node/80566. Accessed on 18 February 2017.

Lanteigne, Marc. 2016. Chinese foreign policy: an introduction. 3rd ed. New York: Routledge.

Lillis, Joanna. 2014. 'Putin fails to win Ukraine consensus at SCO Summit', Eurasianet.org, 12 September. http://www.eurasianet.org/node/69961. Accessed on 18 February 2017.

Liu, Guoli. 2016. China rising: Chinese foreign policy in a changing world. New York: Palgrave.

MacFarquar, Neil. 2016. 'With Trump, Russia goes from Thursday's foe of U.S. to Friday's friend', The New York Times, 31 December. https://www.nytimes. com/2016/12/31/world/europe/trump-russia-us-foe-to-friend.html?_r=0. Accessed on 18 February 2017.

Ministry of Foreign Affairs of the People's Republic of China. 2008. 'Foreign Ministry spokesperson Jiang Yu's regular press conference on September 4, 2008', http://houston.china-consulate.org/eng/nv/fyrth/t513362.htm. Accessed on 18 February 2017.

Ministry of Foreign Affairs of the People's Republic of China. 2014. 'Foreign Ministry spokesperson Qin Gang's regular press conference on March 4, 2014'. 
http://www.china-un.org/eng/fyrth/t1134077.htm. Accessed on 18 February 2017.

Ministry of Foreign Affairs of the Republic of Uzbekistan. 2016. 'The Tashkent Declaration of the Fifteenth Anniversary of the Shanghai Cooperation Organization'. 26 June. http://www.mfa.uz/en/press/sco-uzbekistan/ 2016/06/7780. Accessed on 18 February 2017.

Misra, Ashutosh. 2013. 'Will the emerging India ever arrive?' Griffith Asia Journal l(1): 53-78.

Neumann, Iver B. 1996. Russia and the idea of Europe: a study in identity and international velations. London: Routledge.

Pallin, Carolina Vendil and Fredrik Westerlund. 2009. 'Russia's war in Georgia: lessons and consequences', Small Wars and Insurgencies 20(2): 400-24.

Pillalamarri, Akhilesh. 2014. 'The United States just closed its last base in Central Asia', The Diplomat, 10 June. http://thediplomat.com/2014/06/the-unitedstates-just-closed-its-last-base-in-central-asia. Accessed on 18 February 2017.

Polese, Abel and Slavomir Horák. 2015. 'A tale of two presidents: personality cult and symbolic nation-building in Turkmenistan', Nationalities Papers 43(3): 457-78.

Putz, Catherine. 2016. 'China pushes One Belt, One Road in Central Asia', The Diplomat, 24 May. http://thediplomat.com/2016/05/china-pushes-onebelt-one-road-in-central-asia. Accessed on 18 February 2017.

Reed, J. Todd and Diana Raschke. 2010. The ETIM: China's Islamic militants and the global terrorist threat. Santa Barbara, CA: Praeger.

Reuters. 2015. 'China premier says respects Ukraine integrity, won't be drawn on Crimea', 15 March. http://www.reuters.com/article/us-china-parliamentukraine-idUSKBNOMB05220150315. Accessed on 18 February 2017.

Roberts, Dan. 2016. 'Obama delays US troop withdrawal from "precarious" Afghanistan', The Guardian, 6 July. https://www.theguardian.com/usnews/2016/jul/06/obama-delays-us-troop-withdrawal-afghanistan-al-qaida. Accessed on 18 February 2017.

RT. 2014. 'Russia and China seal historic $\$ 400$ bn gas deal', 21 May. https:// www.rt.com/business/160068-china-russia-gas-deal. Accessed on 18 February 2017.

Russian Government. 2016. 'Meeting of the SCO Council of Heads of Government', 3 November. http://government.ru/en/news/25170. Accessed on 18 February 2017.

Salimov, Oleg. 2014. 'SCO-CSTO merger raised at Dushanbe Conference', CACI Analyst, 4 June. https://www.cacianalyst.org/publications/field-reports/ item/12983-sco-csto-merger-raised-at-dushanbe-conference.html. Accessed on 18 February 2017.

Savic, Bob. 2016. 'Behind China and Russia's "special relationship", The Diplomat, 7 December. http://thediplomat.com/2016/12/behind-chinaand-russias-special-relationship. Accessed on 18 February 2017. 
SCO. 2002. 'Shanghai Cooperation Organisation Charter'. http://www.soi.org. br/upload/34b4f65564132e7702726ee2521839c790b895453b6de5509cfl f997e9e50405.pdf. Accessed on 18 February 2017.

Shambaugh, David. 2008. China's Communist Party: atrophy and adaptation. Berkeley, CA: University of California Press.

Sheives, Kevin. 2006. 'China turns West: Beijing's contemporary strategy towards Central Asia’, Pacific Affairs 79(2): 205-24.

Snetkov, Aglaya and Marc Lanteigne. 2015. "The loud dissenter and its cautious partner" - Russia, China, global governance and humanitarian intervention', International Relations of the Asia-Pacific 15(1): 113-46.

Storey, Ian and Anton Tsvetov. 2016. 'The limits to Russia's pivot to Asia', Wall Street Journal, 18 May.

TASS. 2016. 'Moldova plans to sign free trade agreement with China', 14 September. http://tass.com/economy/899656. Accessed on 18 February 2017.

Taylor, Frederick. 2013. The downfall of money: Germany's hyperinflation and the destruction of the middle class. London: Bloomsbury.

Topuria, Rivaz. 2016. 'Georgia: the key to China's "Belt and Road"', The Diplomat, 28 April. http://thediplomat.com/2016/04/georgia-the-key-tochinas-belt-and-road. Accessed on 18 February 2017.

Wang, Zheng. 2012. Never forget national humiliation: historical memory in Chinese politics and international relations. New York: Columbia University Press.

Way, Lucien. 2008. 'The real causes of colour revolutions', Journal of Democracy 19(3): 55-69.

Westwood, John N. 1988. Endurance and endeavour: Russian history 1812-1986. 3rd ed. Oxford: Oxford University Press.

Wilhelmsen, Julie. 2014. 'Russland, folkeretten og militær intervensjon: selektiv prinsippfasthet' [Russia, international law and military intervention: selective firmness of principles]. Internasjonal Politikk 72(1): 135-46.

Wilhelmsen, Julie and Geir Flikke. 2011. 'Chinese-Russian convergence and Central Asia', Geopolitics 16(4): 865-901.

$\mathrm{Xi}$, Jinping. 2014. The governance of China. Beijing: Foreign Languages Press.

Xinhua. 2014. 'China focus: China's Xi proposes security concept for Asia', 21 May. http://news.xinhuanet.com/english/china/2014-05/21/c_l33351210.htm. Accessed on 18 February 2017.

Xinhua. 2016. 'China, Georgia eye greater cooperation on Silk Road Economic Belt Initiative', 4 June. http://news.xinhuanet.com/english/2016-06/04/ c_135411583.htm. Accessed on 18 February 2017.

Xinhua. 2017. 'China, Georgia ink free trade agreement', 14 May. http://news. xinhuanet.com/english/2017-05/14/c_136280144.htm. Accessed on 24 June 2017. 
Yang, Sheng. 'SCO to expand as Xi attends summit', 6 June. http://www.globaltimes.cn/content/1050352.shtml. Accessed on 24 June 2017.

Zhang, Yunling. 2016. 'China and its neighbourhood: transformation, challenges and grand strategy', International Affairs 92(4): 245-66.

Open Access This chapter is licensed under the terms of the Creative Commons Attribution 4.0 International License (http://creativecommons.org/licenses/ by $/ 4.0 /)$, which permits use, sharing, adaptation, distribution and reproduction in any medium or format, as long as you give appropriate credit to the original author(s) and the source, provide a link to the Creative Commons license and indicate if changes were made.

The images or other third party material in this book are included in the book's Creative Commons license, unless indicated otherwise in a credit line to the material. If material is not included in the book's Creative Commons license and your intended use is not permitted by statutory regulation or exceeds the permitted use, you will need to obtain permission directly from the copyright holder.

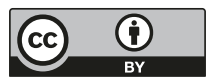

